\title{
Destinasyon Pazarlama Organizasyonlarının Sosyal Medya Performansının Kıyaslanması
}

The Comparison of Destination Marketing Organizations' Social Media Performance

\author{
Doğuş KILIÇARSLAN*, Tahir ALBAYRAK** \\ *(Sorumlu Yazar), Arş. Gör., Akdeniz Üniversitesi, Turizm Fakültesi, Turizm İ̧̧letmeciliği, 07058, Kampus, Antalya. \\ E-posta: doguskilicarslan@gmail.com \\ ORCID NO: 0000-0001-8861-6851 \\ **Doç. Dr., Akdeniz Üniversitesi, Turizm Fakültesi, Turizm İşletmeciliği, 07058, Kampus, Antalya. \\ E-posta: tahiralbayrak@akdeniz.edu.tr \\ ORCID NO: 0000-0001-6961-0550
}

MAKALE BILGILERI

Makale işlem bilgileri:

Gönderilme tarihi: 26 Eylül 2018

Düzeltme: 7 Kasım 2018

Düzeltme: 21 Kasım 2018

Kabul: 22 Kasım 2018

Anahtar sözcükler: Sosyal medya, Destinasyon, Destinasyon pazarlama organizasyonu, Ziyaretçi sayısı.

\section{ARTICLE INFO}

Article history:

Submitted: 26 September 2018

Resubmitted: 7 November 2018

Resubmitted: 21 November 2018

Accepted: 22 November 2018

Key words: Social media, Destination, Destination marketing organisation,

Number of visitors.

\section{ÖZ}

Sosyal medya, Destinasyon Pazarlama Organizasyonları (DPO) tarafından alternatif bir pazarlama/tanıtım kanalı olarak kullanılmasına karşın, destinasyonların sosyal medya performansını ele alan araştırmalar kısıtı sayıdadır. Bu çalışmada, ziyaretçi sayısı açısından Avrupa'da ilk 10 sırada yer alan şehirlere ait DPO'ların Facebook, Youtube, Instagram ve Twitter performansı kıyaslanmıştır. Bulgular Avrupa'nın en çok ziyaret edilen 10 destinasyonu içerisinde Londra'nın Facebook, Twitter ve Instagram'da diğer destinasyonlara kıyasla daha aktif olduğunu ortaya koymaktadır. Türkiye'nin en fazla turist çeken destinasyonları olan İstanbul ve Antalya, bu üç platformda son sıralarda yer almaktadır. Diğer platformlara kıyasla Youtube'un DPO'lar tarafından çok fazla kullanılmadığı tespit edilmiştir. Ayrıca Facebook, Twitter ve Instagram performansı ile destinasyonların ziyaretçi sayısı arasında anlamlı bir iliş̧ki tespit edilmiştir.

\section{Giriş}

Dünya nüfusunun yüzde 42 'sinin aktif olarak kullandığ 1 sosyal medya (Wearesocial 2018), potansiyel turistlerin seyahat planlama aşamasında en fazla yararlandıkları bilgi kaynaklarından biri olmuştur (Buhalis ve Law 2008). Örneğin, 2018 yılında yapılan bir araştırma, Amerikalıların yüzde 54,6'sının seyahat planları için sosyal medyayı kullandıklarını ortaya koymuştur (Statista 2018). Milenyum kuşağının yüzde 87 'si farklı seyahat fikirleri edinmek için bir sosyal medya platformu olan Facebook'tan yararlandiklarını belirtmektedir (Brown 2018). Sosyal medyanın turizm sektörünün gelişimi ve turist davranışı üzerinde giderek artan bir etkiye sahip olması, destinasyonların pazarlama stratejileri içerisinde bu yeni pazarlama platformuna da yer verilmesini gerekli kılmaktadır. Nitekim son yıllarda Destinasyon Pazarlama Organizasyonları' nın (DPO) yüzde 60 'tan fazlasının sosyal medya faaliyetlerine bütçe ayırmaya başladığ 1 tespit edilmiştir (Lund, Cohen ve Scarles 2018). 
Lu, Chen ve Law (2018) tarafından yürütülen çalışmaya göre sosyal medya ile ilgili araştırmalar "sosyal medyanın rolü ve etkileri", "sosyal medya kullanıcılarının davranışları", "sosyal medyanın içeriği" ve "alanyazın taraması" olmak üzere dört ana başlık altında toplanmaktadır. DPO'ların pazarlama başarısı için sosyal

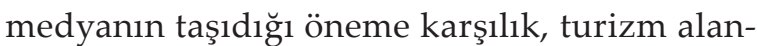
yazınında bu organizasyonların sosyal medya stratejilerini ele alan ve karşılaştıran çalışmaların sınırlı sayıda olduğu dikkat çekmektedir (Uşak11, Koç ve Sönmez 2017). Türkçe alanyazında ise yazarların bilgisi dâhilinde bu tarz bir çalışma bulunmamaktadır. Dolayısıyla, DPO'ların sosyal medya kullanımı konusundaki akademik bilgi birikiminin ilave çalışmalarla zenginleştirilmesi gerekmektedir. Bahsedilen alanyazın boşluğundan yola çıkılarak gerçekleştirilen bu çalışmanın, iki temel amacı bulunmaktadır. Bunlar:

(1) Avrupa'nın en fazla turist çeken on şehrine ait DPO'ların sosyal medya performansinı tespit etmek ve kıyaslamak,

(2) Destinasyon sosyal medya performansı ile ziyaretçi sayısı arasında bir ilişki olup olmadığını araştırmaktır.

Bu çalışmanın ilgili alanyazına sağlayacağı başlıca katkılar arasında Avrupa'nın en fazla ziyaret edilen destinasyonlarının sosyal medya performansının ölçülmesi; destinasyon pazarlaması açısından sosyal medyanın taşıdığı önemin ortaya konulmasi; Avrupa'daki başlıca destinasyonların yanı sıra İstanbul ve Antalya'ya ait sonuçların elde edilmesi ve bu sayede ilgili destinasyonlarla Avrupa'daki destinasyonlar arasında performans kıyaslaması yapılması gibi hususlar yer almaktadır.

\section{SOSYAL MEDYANIN GELIŞiMI VE TURIZM SEKTÖRÜNE ETKILERI}

Sosyal medya, Web 2.0 kullanan ve internet kullanıcılarının bütün dünyada birbirleriyle etkileşime geçmesine ve iletişim kurmasına, deneyim, bilgi ve fikirlerini paylaşmasına olanak sağlayan bir grup internet tabanlı uygulama olarak tanımlanmaktadır (Kaplan ve Haenlein 2010; Xiang ve
Gretzel 2010). Sosyal medyanın gelişmesinden önce, Web 1.0 olarak tabir edilen dönemde internet kullanıcıları web sitelerini okumak, gözlemlemek ve bilgi edinmek amaciyla ziyaret etmekte ve ürün satın almaktaydı. Bu dönemde internet kullanıcılarının içerik oluşturma veya bir içeriğe yorum yapma gibi olanakları bulunmamaktaydı. Diğer bir ifadeyle, Web 2.0'dan önce internet sadece tek yönlü bir iletişime olanak sağlamaktay$\mathrm{d}_{1}$ ve kullanıcıların birbirleriyle etkileşime geçme olanakları oldukça sınırlıydı. Web 2.0'ın hayata geçmesi ile birlikte internet ortamındaki kullanıcılar sadece web sitelerinde yazılanları okumanın ötesine geçerek kendi fikirlerini yazmaya, yazdıklarını diğer kullanıcılarla paylaşmaya, işletmelerle ve diğer kullanıcılarla karşılıklı iletişim kurmaya başladılar (Aghaei, Nematbakhsh ve Farsani 2012). İşletmeler, kamu kurumları, sivil toplum örgütleri, münferit kullanıcılar gibi farklı gruplar arasında karşılıklı bir iletişimin sağlanması ile internet ortamı 'sosyal' bir yapı kazanmıştır. Bilhassa Web 2.0 döneminin ardından internet kullanıcılarının kendi içeriklerini oluşturmaya başlaması, tüketici davranışında da önemli değişimlere yol açmıştır.

Yukarıda açıklanan gelişmeler insanların bilgi arama ve seyahat planı yapma biçimlerini de değiştirmiştir (Buhalis ve Law 2008). Kaplan ve Haenlein'e (2010) göre bu değişimler, turizm sektörünü üç temel alanda etkilemiştir. İlk olarak, internet altyapısının gelişmesi Trip Advisor, Virtual Tourism ve Independent Traveler gibi seyahat ve turizm ile ilgili konuların tartışıldığı, çevrimiçi toplulukların ortaya çıkmasına ve hızla artmasına zemin hazırlamıştır. Özellikle Facebook ve Instagram gibi genel sosyal medya kanalları, seyahat ve turizm başlıklı kullanıcı gruplarının oluşmasını yaygınlaştırmıştır. İkinci olarak, internetin gelişimi ve yaygınlaşması, kullanıcıların seyahat ve turizm ile ilgili bilgi arama ve planlama davranışlarını değiştirmiştir. Üçüncü olarak, turizm işletmeleri sosyal medyayı pazarlama stratejilerinin önemli bir unsuru olarak kullanmaya başlamıştır. Sosyal medya, teknoloji ile paralel olarak hızlı bir değişim gösterdiğinden, bu alanda yapılan bilimsel araştırmaların sayısı da sürekli artmaktadır. 


\section{DESTINASYON PAZARLAMA ORGANIZASYONLARI'NIN PAZARLAMA STRATEJILERI IÇINDE SOSYAL MEDYANIN YERi}

Destinasyon pazarlama organizasyonları (DPO) belirli bir coğrafi alanın turistik unsurlarını ve çekiciliklerini göz önüne alarak, bu unsurlara yönelik pazarlama çalışmalarını yürüten kurumlardır. DPO'lar yerel, bölgesel, ulusal ve uluslararası düzeyde faaliyet gösterebilirler (yerel düzeyde Antalya Tanıtım Vakfı; bölgesel düzeyde Akdeniz Turistik Otelciler ve İşletmeciler Birliği ve Avrupa Turizm Derneği -European Tourism Association- gibi). Munar'a (2012) göre destinasyon pazarlama organizasyonlarının üç ana fonksiyonu bulunmaktadır. Bunlardan ilki, destinasyon markalaşmasını sağlamak ve destinasyon bilgi yönetimini kurmak için kurumlar ve kuruluşlar arasında iş birliğinin ve koordinasyonun sağlanmasıdır. İkincisi, destinasyonun gelişmesi için gerek duyulan düzenlemelerin ve girişimlerin gerçekleştirilmesine yardımcı olmaktır. Üçüncüsü, destinasyon turizm planlaması ile bölgesel kalkınma arasında uyum sağlamaktır.

Son yillarda birçok ülkede yaşanan ekonomik istikrarsızlıklar sebebiyle DPO'ların kamu kurumlarından aldıkları finansal destekler azalmaya başlamıştır (Hays, Page ve Buhalis 2013). Örneğin, İngiltere'nin destinasyon pazarlama kuruluşu olan 'Visit Britain', 2010 yılında devlet desteğinin yüzde 34'ünü kaybettiğinden, 70 çalışanını işten çıkarmak ve 14 denizaşırı ofisini kapatmak zorunda kalmıştır (Johnson 2011). Azalan finansal kaynaklarından dolayı, birçok DPO diğer pazarlama araçlarına göre daha az maliyet yaratan sosyal medya ortamını tercih etmeye ve pazarlama faaliyetlerinde sosyal medyayı daha etkin bir şekilde kullanmaya başlamıştır (Hays, Page ve Buhalis 2013).

Günümüzde DPO'ların dışında turizmle ilgili diğer kurum ve kuruluşlar da pazarlama stratejileri kapsamında sosyal medyayı daha etkin şekilde kullanmaya başlamışlardır. Çünkü ilgili alanyazında yapılan birçok araştırmada da ortaya konulduğu üzere, sosyal medyanın gelişimine uyum sağlayamayan turizm organizasyonları rekabet avantajindan yoksun kalmaktadır (Schegg vd. 2008; Stankov, Lazić ve Dragićević 2010; Hays, Page ve Buhalis 2013). Buna karşılık, sosyal medyanın doğru bir şekilde kullanılmaması, sosyal medyayı hiç kullanmamaktan daha vahim sonuçlar da doğurabilmektedir (Schegg vd. 2008). Örneğin, sosyal medya ortamında potansiyel turistlerin sorularına geç, eksik veya yanlış cevap veren, müşteri sorunlarına ve şikayetlerine hızla doğru çözümler üretemeyen turizm işletmelerinin yaşadıkları kayıplar, sosyal medya kullanmayan işletmelere göre daha fazla olabilmektedir.

DPO'ların sosyal medya kullanımını konu alan çalışmalarda genellikle bu organizasyonların sosyal medya performansı açısından karşılaştırıldıkları görülmektedir. Örneğin, bu konuda ilk araştırmalardan birini gerçekleştiren Ružić ve Biloš (2010), Hirvatistan'daki 20 idari bölge DPO'sunun sosyal medya stratejilerini incelemiştir. Sonuçlar DPO'ların sosyal medya platformları bir yana, web sitelerini dahi verimli bir şekilde kullanmadıklarını ortaya koymuştur. Milwood, Marchiori ve Zach (2013), çalışmalarında ABD'deki ve İsviçre'deki DPO'ları sosyal medyaya uyum sağlama ve yönetme etkinliği açısından karşılaştırmıştır. DPO temsilcilerinden (72 İsviçreli ve 103 ABD'li olmak üzere) elektronik anket yöntemiyle elde edilen sonuçlar, ABD'deki DPO temsilcilerinin sosyal medyaya yüksek oranda uyum sağlandığı düşüncesinde olduklarını; buna karşılık, İsviçre DPO temsilcilerinin mevcut organizasyon yapılarının bu uyumu engellediği kanısında olduklarını göstermiştir.

Hays, Page ve Buhalis (2013), on ülkenin (Meksika, Malezya, Almanya, Birleşik Krallık, Türkiye, Fransa, İspanya, Almanya, Çin ve İtalya) DPO'larını Facebook ve Twitter kullanımları açısından kıyaslamıştır. Çalışma sonucunda Malezya' nın on ülke içerisinde ilk Twitter hesabı oluşturan ve en çok takipçiye sahip olan ülke olduğu belirlenmiştir. Ayrıca, Facebook sayfasındaki beğeni sayısı açısından İspanya'nın ilk sırada olduğu tespit edilmiştir. Araştırmanın yapıldığı dönemde Türkiye'nin Facebook üyeliğinin olmaması ve Twitter performansı açısından son sıralarda yer alması dikkat çekmektedir. Uşaklı, Koç ve Sönmez (2017) tarafından gerçekleştirilen 
bir başka araştırmada Facebook, Twitter, Instagram ve Youtube gibi dünyanın en fazla kullanıc1 sayısına sahip sosyal medya platformlarina ilk üye olan beşülkenin DPO'ları incelenmiştir. Türkiye söz konusu platformlarda ilk hesap açan ülkeler arasında bulunmamaktadır. Diğer bir ifadeyle, rakip destinasyonlarla kıyaslandığında Türkiye'nin sosyal medyaya uyum sürecinde geç kaldığı tespit edilmiştir. Buna karşın, bahsedilen çalışmaya ait sonuçlar kullanıcı yorumlarına dayalı olarak ölçülen müşteri bağlılığı kapsamında Türkiye'nin Avrupa ülkeleri içerisinde en yüksek sosyal medya müşteri bağlılığına sahip ülke olduğunu göstermiştir. Diğer bir çalışmada, Roque ve Raposo (2016) tarafından 13 ülkenin DPO'su sosyal medya kullanımları açısından kıyaslanmıştır. Sonuçlar, Facebook, Twitter ve Youtube'un genellikle DPO'ların en çok kullanıldıkları sosyal medya platformları olduğunu; ancak DPO'ların kullanıcılarıyla etkileşimlerinde önemli farklılıklar bulunduğunu ortaya koymuştur. Örneğin, DPO'ların çoğunluğu kendi ülke dilinde ve İngilizce paylaşım yapmasına karşın, bazı DPO'lar hedef aldıkları ülkelerin dillerinde de paylaşım yapmaktadır.

\section{YÖNTEM}

Bu çalışmada Avrupa kıtasının turistler tarafından en fazla ziyaret edilen 10 şehri (Euromonitor International 2017) olan Londra, Paris, Roma, İstanbul, Prag, Barselona, Milano, Amsterdam,
Antalya ve Viyana'nın sosyal medya performansı karşılaştırılmıştır. Araştırma, ilgili şehirlerin resmi destinasyon pazarlama organizasyonu web siteleri ve web sitelerinde kayitlı sosyal medya hesaplarına ait güncel bilgiler esas alınarak gerçekleştirilmiştir. Sosyal medya hesaplarının tespitinde ve incelenmesinde, aylık kullanıcı sayısı en yüksek sosyal medya platformlarının kullanılması kararlaştırılmıştır. Bunlar, sırasıyla Facebook (2.130.000.000), Youtube (1.500.000.000), Instagram (800.000.000) ve Twitter'dır (330.000.000) (Dreamgrow 2018). Ancak, DPO'ların web siteleri incelendiğinde, adı geçen dört sosyal medya kanalının dışında, farklı kanallarda da hesaplarının olduğu görülmüştür. DPO'lardan altı tanesi, Pinterest üyeliğine de sahiptir. Araştırılan DPO'lar tarafından kullanılan diğer sosyal medya platformları Google+, Tripadvisor, İzlesene, Foursquare ve Linkedin'dir.

Destinasyonların sosyal medya performansını değerlendirmek için kullanılacak kriterleri belirlemek maksadıyla, öncelikle ilgili alanyazın incelenmiştir. Bunun sonucunda Facebook için 14, Twitter için 10, Instagram için dokuz ve Youtube için beş kriter tespit edilmiştir. Daha sonra turizm sektöründe çalışan iki sosyal medya uzmanı ile görüşülerek, her iki uzmanın önemli olmad1ğını belirttiği kriterler elenmiş ve her iki uzmanın önerdiği yeni kriterler eklenmiştir. Sonuç olarak, ilgili alanyazın ve uzman görüşleri göz önüne alınarak, DPO'ların Facebook performansını tes-

Tablo 1. DPO'ların Web Sitelerinde Yer Alan Sosyal Medya Hesapları

\begin{tabular}{|c|c|c|c|c|c|c|c|}
\hline Şehir & Ziyaretçi Sayısı & Internet Sitesi & Facebook & Twitter & Instagram & Youtube & Diğer \\
\hline Londra & 19.842 .800 & visitlondon.com & + & + & + & + & Pinterest, Google+ \\
\hline Paris & 14.263 .000 & parisinfo.com & + & + & + & + & Pintrest, TripAdvisor \\
\hline Roma & 9.396 .400 & turismoroma.it & + & + & + & + & - \\
\hline İstanbul & 8.642 .300 & istanbulkulturturizm.gov.tr & + & + & + & + & İzlesene \\
\hline Prag & 8.550 .700 & prague.eu & + & + & + & - & Pinterest \\
\hline Barselona & 7.624 .100 & barcelonaturisme.com & + & + & + & + & Pinterest, Google+ \\
\hline Milano & 6.882 .500 & turismo.milano.it & + & + & + & + & Foursquare \\
\hline Amsterdam & 6.570 .400 & iamsterdam.com & + & + & + & - & Pintrest, Linkedin \\
\hline Antalya & 6.457 .400 & antalyadestination.com & + & + & + & $+\mathrm{Pi}$ & interest, Linkedin, Google+ \\
\hline Viyana & 6.043 .700 & wien.info & + & - & + & + & - \\
\hline
\end{tabular}


pit etmek için 10, Twitter performansı için sekiz, Instagram performansı için yedi, Youtube performansı için yedi kriterin kullanılmasına karar

Ele alınan destinasyonların kullandıkları sosyal medya kanallarının tespitinde ve incelenmesinde DPO'lara ait web siteleri esas alınmıştır. Bu DPO'ların bazıları kamu ve özel sektör iş birliğiyle gerçekleşen kurumlar iken (örneğin Antalya Tanıtım Vakfı'na ait antalyadestination.com) bazıları ise sadece kamu kaynaklarıyla oluşturulan kurumlardır (örneğin, İstanbul Kültür ve Turizm Müdürlüğü'ne ait istanbulkulturturizm.gov.tr). Tablo 1'de değerlendirmeye alınan DPO'ların sahip oldukları sosyal medya kanalları gösterilmiştir. Buna göre, bütün DPO'ların Facebook ve Instagram hesapları bulunmaktadır. Prag ve Viyana'nın Youtube platformunda resmi hesapları bulunmamaktadir. Twitter hesabı olmayan tek DPO Viyana şehrine aittir. Ayrıca Roma ve Viyana'nın dört büyük sosyal medya platformu dışındaki platformlarda hesapları olmadığı tespit edilmiştir. DPO'ların birçoğu Pinterest'te de hesap sahibidir.

DPO'ların sosyal medya hesaplarına ait veri 01 Ocak 2017 - 31 Aralık 2017 tarihleri arasında yapılan paylaşımlara dayanmaktadır. Sosyal medya kanalları için tespit edilen kriterlere uygun veri toplama işlemleri hem araştırmacılar tarafından manuel olarak hem de 'fanpagekarma.com' şirketine ait bir uygulama yardımıyla gerçekleştirilmiştir.

\section{BULGULAR}

\section{DPO'ların Facebook performansı}

DPO'lara ait resmi Facebook sayfalarının performansı belirlenen kriterler esas alınarak tespit edilmiş ve sonuçlar karşılaştırmalı olarak Tablo 2'de gösterilmiştir. Beğenen ve takipçi sayısı incelendiğinde Londra'nın diğer destinasyonlardan daha üstün bir performans gösterdiği görülmektedir. Beğenen ve takipçi sayılarında Londra'yı sirasiyla Amsterdam, Paris, Viyana, Prag ve Barselona takip ederken, diğer destinasyonların beğenen ve takipçi sayıları 100.000'in altında kalmiştır.

Facebook hesabından günlük en fazla paylaşım yapan DPO Roma iken bunu Londra DPO'su takip etmektedir. Diğer DPO'ların günlük paylaşımları ikiden az ortalamaya sahip olup, İstanbul günlük paylaşım sayısı en az DPO olarak dikkat çekmektedir. Gönderilere yapılan beğeni, yorum ve paylaşım kriterleri incelendiğinde Londra'nın bu kriterlerde de en başarılı DPO olduğu görülmektedir. Antalya, en düşük performansa sahip

Tablo 2. DPO'ların Facebook Performansı

\begin{tabular}{|c|c|c|c|c|c|c|c|c|c|c|}
\hline Şehir & Beğenen & Takipçi & $\begin{array}{c}\text { Gönderi/ } \\
\text { Gün }\end{array}$ & Beğeni & Yorum & Paylaşım & $\begin{array}{l}\text { Beğeni/ } \\
\text { Gönderi }\end{array}$ & $\begin{array}{l}\text { Yorum/ } \\
\text { Gönderi }\end{array}$ & $\begin{array}{r}\text { Paylaşım/ } \\
\text { Gönderi }\end{array}$ & Foto \\
\hline Londra & 1.281 .896 & 1.266 .675 & 3,31 & 5.060 .666 & 113.180 & 413.140 & 4.189 & 94 & 342 & 434 \\
\hline Paris & 385.107 & 383.303 & 0,76 & 187.248 & 22.029 & 33.045 & 674 & 79 & 118 & 130 \\
\hline Roma & 58.116 & 57.697 & 4,75 & 119.891 & 2.933 & 16.265 & 69 & 2 & 9 & 1.659 \\
\hline İstanbul & 1.624 & 1.673 & 0,65 & 2.289 & 16 & 745 & 10 & 0,07 & 3 & 197 \\
\hline Prag & 218.319 & 216.320 & 1,00 & 715.483 & 16.665 & 48.481 & 1.944 & 45 & 132 & 358 \\
\hline Barselona & 106.156 & 104.187 & 0,92 & 106.588 & 3.565 & 10.740 & 318 & 11 & 32 & 303 \\
\hline Milano & 67.611 & 67.573 & 1,35 & 61.543 & 1.999 & 17.531 & 125 & 4 & 36 & 453 \\
\hline Amsterdam & 830.619 & 809.296 & 1,04 & 745.202 & 29.060 & 89.729 & 1.951 & 76 & 235 & 327 \\
\hline Antalya & 1.610 & 1.527 & 1,27 & 356 & 10 & 145 & 1 & 0,02 & 0,31 & 233 \\
\hline Viyana & 249.570 & 239.943 & 1,30 & 324.035 & 12.336 & 46.883 & 862 & 33 & 125 & 281 \\
\hline
\end{tabular}

Not: Beğenen kriteri sayfayı beğenenlerin sayısını, beğeni kriteri ise sayfanın paylaştığı gönderilerin beğenilme sayısını göstermektedir. 
Tablo 3. DPO'ların Twitter Performansı

\begin{tabular}{lrrrrrrrr}
\hline Şehir & Takipçi & Takip & Tweet & Tweet/Gün & Beğeni & Retweet & $\begin{array}{r}\text { Beğeni } \\
\text { ortalaması }\end{array}$ & $\begin{array}{r}\text { Retweet } \\
\text { ortalaması }\end{array}$ \\
\hline Londra & 665.522 & 4.440 & 4.782 & 13,1 & 342.054 & 106.667 & 71,5 & 22,3 \\
\hline Paris & 336.847 & 1.660 & 1.906 & 5,2 & 7.641 & 41.440 & 56,7 & 21,7 \\
\hline Roma & 95.680 & 1.275 & 2.286 & 6,3 & 60.125 & 23.455 & 26,3 & 10,3 \\
\hline İstanbul & 5.410 & 65 & 153 & 0,4 & 1.372 & 724 & 9,0 & 4,7 \\
\hline Prag & 15.245 & 414 & 722 & 2,0 & 21.585 & 5.957 & 28,9 & 8,3 \\
\hline Barselona & 16.012 & 1.472 & 1.737 & 4,8 & 8.678 & 3.132 & 5,0 & 1,8 \\
\hline Milano & 51.804 & 538 & 1.383 & 3,8 & 13.406 & 6.929 & 9,7 & 5,0 \\
\hline Amsterdam & 408.287 & 441 & 890 & 2,4 & 30.860 & 10.427 & 34,7 & 11,7 \\
\hline Antalya & 2.784 & 899 & 440 & 1,20 & 1.034 & 563 & 2,35 & 1,28 \\
\hline
\end{tabular}

*Viyana, resmi Twitter hesabı bulunmaması sebebiyle tabloda yer almamaktadır.

DPO'dur. Ayrıca, görsel anlamda (fotoğraf) en çok paylaşım yapan DPO Roma, en az paylaşımı yapan DPO İstanbul'dur.

\section{DPO'ların Twitter performansı}

DPO'ların Twitter performansına ilişkin sonuçlar Tablo 3'te karşılaştırmalı olarak sunulmuştur. Viyana'nın resmi Twitter hesabı bulunmadığı için dokuz destinasyon arasında karşılaştırma yapılmıştır. Londra Facebook platformundaki gibi en çok takipçiye sahip destinasyon iken, Londra'yı sirasiyla Amsterdam, Paris ve Roma takip etmektedir. En az takipçiye sahip destinasyonlar ise sırasıyla Antalya, İstanbul ve Prag'tır. Tweet sayıları ve buna bağlı günlük ortalama tweet sayıları incelendiğinde, Londra'nın ilk sırada yer aldığı, ardından Roma, Paris, Barselona ve Milano'nun geldiği görülmektedir. En az tweet atan destinasyonlar ise sirasiyla İstanbul, Antalya ve Prag'dır. Paylaşılan tweetlerin beğenilmesi ve tekrar paylaşılması (retweet) kriterlerinde de Londra destinasyonu ilk sirada yer alırken, tweetlerin beğenilmesinde Londra'yı sırasıyla Roma, Amsterdam ve Prag takip etmiştir. Tekrar paylaşma kriterinde ise Londra'dan sonra s1rasiyla Paris, Roma ve Amsterdam gelmektedir. Antalya'nın atılan tweetlerin beğenilmesi ve tekrar paylaşılması konusunda en son sırada yer aldığı tespit edilmiştir.

\section{DPO'ların Instagram performansı}

Belirlenen kriterlere göre destinasyonların Instagram performansına ait sonuçlar Tablo 4'te karşılaştırmalı olarak gösterilmiştir. Instagram'da en çok takipçiye sahip destinasyon Paris iken, ardindan Londra, Barselona ve Amsterdam gelmektedir. Antalya, İstanbul ve Prag ise sirasiyla en az takipçiye sahip destinasyonlardır. En çok gönderi yapan destinasyon Amsterdam olmasına karşın, gönderileri en çok beğenilen destinasyon Londra'dır. Bu husus Londra'nın daha aktif takipçilere sahip olduğunu göstermektedir. Amsterdam'ın ardından Londra ve Roma en çok gönderiye sahip destinasyonlardır. Paris ve Amsterdam ise Londra'nın ardından gönderileri en çok beğenilen destinasyonlar konumundadır. Antalya, İstanbul ve Prag her iki kritere göre son sıralardadır. Gönderilere yapılan yorum sayıları incelendiğinde, sırasıyla Londra, Amsterdam ve Paris'in ilk üç sırada yer aldığı görülmektedir. İstanbul, Antalya ve Roma son siralarda yer almıştır. Facebook ve Twitter'den farklı olarak Instagram'da en çok takipçisi olan destinasyonun Paris olması dikkat çekmektedir.

\section{DPO'ların Youtube performansı}

Araştırılan DPO'ların Youtube hesaplarının performansını belirleyen kriterlere ait sonuçlar, Tablo 5'te karşılaştırmalı biçimde sunulmuştur. 
Tablo 4. DPO'ların Instagram Performansı

\begin{tabular}{lrrrrrrr}
\hline Destinasyon & Takipçi & $\begin{array}{c}\text { Takip } \\
\text { edilen }\end{array}$ & $\begin{array}{r}\text { Gönderi } \\
\text { sayısı }\end{array}$ & Beğeni & Yorum & $\begin{array}{r}\text { Beğeni } \\
\text { ortalaması }\end{array}$ & $\begin{array}{r}\text { Yorum } \\
\text { ortalaması }\end{array}$ \\
\hline Londra & 301.527 & 2.324 & 557 & 4.062 .453 & 28.821 & $7.293,5$ & 51,7 \\
\hline Paris & 376.071 & 527 & 328 & 2.957 .186 & 19.680 & $9.015,8$ & 60,0 \\
\hline Roma & 28.982 & 563 & 448 & 190.992 & 1.313 & 426,3 & 2,9 \\
\hline İstanbul & 5.904 & 115 & 142 & 1.635 & 7 & 11,5 & 0,1 \\
\hline Prag & 16.568 & 74 & 269 & 139.582 & 1.342 & 518,9 & 5,0 \\
\hline Barselona & 141.116 & 692 & 246 & 1.522 .589 & 17.736 & $6.189,4$ & 72,1 \\
\hline Milano & 29.885 & 137 & 385 & 213.637 & 1.718 & 554,9 & 4,5 \\
\hline Amsterdam & 114.748 & 596 & 992 & 2.858 .903 & 22.234 & $2.882,0$ & 22,4 \\
\hline Antalya & 1.044 & 1.441 & 57 & 2.660 & 22 & 46,7 & 0,4 \\
\hline Viyana & 61.361 & 501 & 397 & 968.007 & 11.263 & $2.438,3$ & 28,4 \\
\hline
\end{tabular}

Barselona DPO'suna ait Youtube hesabının abone sayısı, bu bilgi diğer kullanıcılara kapatılmış olduğu için belirlenememiştir. Tablo 5 incelendiğinde İstanbul DPO'sunun 2017 yılı boyunca Youtube kanalı üzerinden hiç paylaşım yapmadığg dikkat çekmektedir. Buna karşın Paris en çok video paylaşımı yapan destinasyon web sitesidir. Elde edilen verilere göre en çok aboneye sahip olan DPO'lar sırasıyla Londra, Viyana ve Paris'tir. En az aboneye sahip DPO'lar ise s1rasiyla Antalya, İstanbul ve Milano'dur. Viyana paylaştığı videoları en çok izlenen destinasyon olarak öne çıkarken, Antalya abone sayısından daha az toplam görüntülenme sayısıyla destinasyonlar arasında en az izlenme sayısına sahip şehirdir. Paylaşılan videoların beğeni ve yorum sayıları incelendiğinde Viyana'nın ilk sırada yer aldığı görülmektedir. Fakat olumsuz bir kriter olan beğenmeme konusunda da Viyana ilk sıradadır. Bu durumun, Viyana'nın görüntülenme sayısının rakip destinasyonlarla kıyaslandığında çok daha yüksek olmasından kaynaklandığ söylenebilir. Ayrıca, Antalya'nın her üç kriterde de hiçbir etkileşimi olmaması göze çarpmakta-

Tablo 5. DPO'ların Youtube Performansı*

\begin{tabular}{|c|c|c|c|c|c|c|c|}
\hline Şehir & Abone & $\begin{array}{l}\text { Video } \\
\text { sayısı }\end{array}$ & $\begin{array}{r}\text { Toplam } \\
\text { görüntülenme }\end{array}$ & $\begin{array}{r}\text { Ortalama } \\
\text { görüntülenme }\end{array}$ & Beğeni & Beğenmeme & Yorum \\
\hline Londra & 24.966 & 22 & 43.978 & $1.999,0$ & 523 & 23 & 30 \\
\hline Paris & 2.315 & 40 & 81.415 & $2.035,4$ & 405 & 9 & 15 \\
\hline Roma & 930 & 3 & 2.078 & 692,7 & 13 & 0 & 0 \\
\hline İstanbul** & 85 & m.d. & m.d. & m.d. & m.d. & m.d. & m.d. \\
\hline Barselona & m.d. & 26 & 308.504 & $11.865,5$ & 88 & 7 & 5 \\
\hline Milano & 254 & 6 & 181.553 & $30.258,8$ & 72 & 6 & 1 \\
\hline Antalya & 23 & 1 & 20 & 20 & 0 & 0 & 0 \\
\hline Viyana & 17.235 & 33 & 3.463 .224 & $107.306,7$ & 4355 & 2573 & 144 \\
\hline
\end{tabular}

*Prag ve Amsterdam'ın Youtube hesabı olmadığı için tabloda yer verilmemiştir.

**İstanbul'un 2017 yılı içerisinde hiç paylaşımı olmadığı için sadece abone sayısına yer verilmiştir. m.d.: mevcut değil 
Destinasyon Pazarlama Organizasyonlarının Sosyal Medya Performansının Kıyaslanması

Tablo 6. DPO'ların Sosyal Medya Kanallarındaki Performansı ile Ziyaretçi Sayıları Arasındaki İlişki

\begin{tabular}{|c|c|c|c|c|c|c|c|c|c|c|}
\hline & Beğenen & Takipçi & $\begin{array}{l}\text { Gönderi/ } \\
\text { Gün }\end{array}$ & Beğeni & Yorum & Paylaşım & Beğeni/ & $\begin{array}{l}\text { Yorum/ } \\
\text { Gönderi }\end{array}$ & $\begin{array}{l}\text { Paylaşım/ } \\
\text { Gönderi }\end{array}$ & $\begin{array}{l}\text { Fotoğraf } \\
\text { Gönderi }\end{array}$ \\
\hline Facebook $(N=10)$ & $0,693^{* *}$ & $0,700 * *$ & 0,391 & $0,814^{*}$ & $0,845^{*}$ & $0,806^{*}$ & $0,680 * *$ & $0,662 * *$ & $0,626 * * *$ & 0,02 \\
\hline \multirow[t]{3}{*}{ Twitter $(\mathrm{N}=9)$} & Takipçi & Takip & Tweet & Tweet & Beğeni & Retweet & Beğeni & Retweet & & \\
\hline & Edilen & & Gün & & & & Ort. & ort. & & \\
\hline & $0,780 * *$ & $0,891^{*}$ & $0,854^{*}$ & $0,854^{*}$ & $0,834^{*}$ & $0,960 *$ & $0,879 *$ & $0,861^{*}$ & & \\
\hline \multirow[t]{2}{*}{ Instagram $(\mathrm{N}=10)$} & Takipçi & \multirow{2}{*}{\multicolumn{2}{|c|}{ Takip Edilen }} & Gönderi & Beğeni & Yorum & Beğeni & Yorum & & \\
\hline & & & & Sayısı & & & Ort. & Ort. & & \\
\hline $0,789 *$ & $0,635^{* *}$ & 0,123 & $0,711 * *$ & 0,596 & $0,681 * *$ & 0,487 & & & & \\
\hline \multirow[t]{3}{*}{ Youtube ( $N=7$ ) } & Abone & Video & \multirow{2}{*}{\multicolumn{2}{|c|}{ Görüntülenme }} & Beğeni & Beğenmeme & Yorum & & & \\
\hline & & Sayısı & & & & & & & & \\
\hline & 0,564 & 0,336 & $-0,369$ & & $-0,439$ & $-0,228$ & & $-0,339$ & & \\
\hline
\end{tabular}

Not: Tüm kat sayılar, ilgili kriterlerin ziyaretçi sayısıyla arasındaki korelasyonu göstermektedir. ${ }^{*} \mathrm{p}<0,01 ;{ }^{* *} \mathrm{p}<0,05 ;{ }^{* * *} \mathrm{p}<0,1$; diğgerleri anlamsızdır.

dır. Antalya DPO'sunun 2017 yılında paylaştı̆̆1 bir adet video, 20 kişi tarafından izlenmiştir. Genel olarak, incelenen DPO'ların Youtube'de diğer sosyal medya kanallarındaki kadar aktif olmadıkları söylenebilir.

\section{DPO'ların sosyal medya kanallarındaki performansı ile ziyaretçi sayıları arasındaki ilişki}

DPO'ların sosyal medya kanallarındaki performansı ile ziyaretçi sayıları arasında bir ilişki olup olmadığını ortaya koymak maksadıyla bu iki değişken arasındaki ilişki korelasyon analizi ile incelenmiştir (Tablo 6). Analiz sonuçlarına göre DPO'ların Facebook performansını belirleyen kriterler arasında yer alan beğenen sayısı, takipçi sayısı, gönderi başına beğeni sayısı ve gönderi başına yorum sayısı ile destinasyon ziyaretçi sayısı arasında 0,05 düzeyinde, toplam beğeni, toplam yorum, toplam paylaşım sayısı ile ziyaretçi sayısı arasında 0,01 düzeyinde pozitif ve anlam11 bir ilişki olduğu saptanmıştır. Ancak günlük gönderi sayısı, gönderi başına paylaşım sayısı ve fotoğraf sayısı ile ziyaretçi sayısı arasında bir ilişki tespit edilememiştir. DPO'ların Twitter performansını belirleyen kriterler ile ziyaretçi sayıları arasındaki ilişki incelendiğinde, takipçi sayısının ziyaretçi sayısı ile 0,05 düzeyinde diğer kriterlerle ise 0,01 düzeyinde pozitif ve anlamlı bir ilişkisi olduğu tespit edilmiştir. Daha sonra, Instagram performansını yansıtan kriterler ile ziyaretçi sayıları arasındaki ilişki incelenmiştir. DPO'ların ziyaretçi sayıları ile takipçi sayıları arasında 0,01 düzeyinde, takip edilen, beğeni ve beğeni ortalaması arasında 0,05 düzeyinde pozitif ve anlamlı bir ilişki olduğu belirlenmiştir. Buna karşın destinasyon ziyaretçi sayısının gönderi sayısı, yorum sayısı ve yorum ortalaması ile herhangi bir ilişkisi olmadığı tespit edilmiştir. Son olarak ziyaretçi sayısı ile Youtube performansını ortaya koyan kriterler arasındaki ilişki incelenmiştir. Analiz sonuçlarına göre ziyaretçi sayısı ile Youtube performansını belirleyen kriterler arasında anlamlı bir ilişki tespit edilememiştir.

\section{SONUÇ VE ÖNERILER}

Destinasyon pazarlamasında önemli bir yere sahip olan sosyal medyanın doğru ve etkili bir biçimde kullanılması gerekmektedir. Bu hususu anlamanın yollarından biri, destinasyonların sosyal medyadaki performansını rakiplerinin performansı ile karşılaştırmalarıdır. Bu çalışmada Avrupa'nin en çok ziyaret edilen 10 kentine ait DPO'ların dört sosyal medya kanalındaki (Facebook, Youtube, Instagram ve Twitter) performansı ölçülerek, elde edilen sonuçlar karşılaştırılmıştır. Ayrıca DPO'ların sosyal medya performansı ile ziyaretçi sayıları arasındaki ilişki incelenmiştir.

Yedi farklı sosyal medya kanalında hesaba sahip olan Antalya, incelenen on destinasyon arasinda en fazla sayıda sosyal medya hesabina 
sahip olandır. Her ne kadar bu durum Antalya DPO'sunun sosyal medyaya verdiği önemin bir göstergesi olarak görünmekte ise de ilgili destinasyonun genel sosyal medya performansi diğer destinasyonlarla kıyaslandığında DPO'nun bu pazarlama ortamında başarılı ve aktif bir biçimde faaliyet göstermediği anlaşılmaktadır. $\mathrm{Bu}$ bağlamda, destinasyonların çok sayıda sosyal medya hesabına sahip olmasının, sosyal medya ortamında başarılı ve rekabetçi olmak için yeterli olmadığı, esasen gösterilen performansın ve bu performansın sürekliliğinin hedeflenmesi gerektiği söylenebilir. Ayrıca, sosyal medya kanalları birbirinden farklı yapıda olduğundan ve farklı niteliklere sahip internet kullanıcıları tarafınca tercih edildiklerinden, DPO'ların web sitelerini ve sosyal medya hesaplarını ziyaret edenlerin beklentilerine hitap edebilen bir sosyal medya yönetim politikasına ve içerik yönetimine sahip olması gerekmektedir. Bu açıdan, DPO'ların birden fazla sayıda sosyal medya kanalında hesap sahibi olmaları daha fazla sayıda ve özellikte kişiye ulaşmalarını sağlayabilir. Ancak, DPO'ların sahip oldukları sosyal medya hesaplarını etkin ve etkili bir şekilde yönetebilmeleri ve sosyal medya platformunda sürekli aktif olmaları gerekmektedir.

Bu çalışmada incelenen DPO'ların Facebook'taki performansı değerlendirildiğinde, günlük olarak yapılan paylaşımlar konusunda Roma'nın birinci, Londra'nın ikinci sırada olduğu görülmüştür. Ancak, beğenen ve takipçi sayısı bak1mından Londra'nın diğer destinasyonlara göre daha başarılı olduğu belirlenmiştir. Bunun yanı sira, Londra DPO'sunun Facebook sayfası, en fazla paylaşım yapan Roma'nın 20 katından fazla beğeni ve takipçi sayısına sahiptir. Bu nedenle, Facebook kanalında paylaşım sayısı ile yapılan paylaşımların beğenilmesi ve takipçi sayısının artması arasında doğrudan bir ilişkinin söz konusu olmadığı söylenebilir. Nitekim gönderilere yapılan yorum, beğeni ve paylaşımlar, sosyal medya ortamında müşteri bağlılığını yansıtan başlıca kriterler arasındadır (Kabadayi ve Price 2014; Uşakl1, Koç ve Sönmez 2017). Bu kriterler dikkate alındığında, Londra destinasyonuna yönelik sosyal medya ortamındaki müşteri bağlıl1ğının, diğer destinasyonlara göre daha yüksek olduğu görülmektedir. Antalya destinasyonu ise bahsedilen kriterler bakımından son sıralarda yer almaktadır. Müşteri bağlılığının başlıca göstergeleri olan sosyal medya sayfasını beğenen ve takip eden kullanıcı sayısının Antalya destinasyonu için öncelikle ele alınması gereken hedefler olduğu açıktır.

Destinasyonların Twitter sosyal medya kanalındaki performansı da ele alınmıştır. Elde edilen sonuçlara göre, Londra, diğer DPO'lara kıyasla en başarılı performansa sahip destinasyondur. En az takipçi sayısına sahip, en az takip eden, tweet atan, diğer bir deyişle Twitter platformunu en pasif şekilde kullanan DPO'lar arasında Antalya, İstanbul ve Prag yer almaktadır. Ancak, Prag'ın beğeni ve retweet sayıları detaylı bir biçimde incelendiğinde, takipçi sayısına oranla bu sayıların oldukça yüksek olduğu dikkat çekmektedir. Dolayısıyla, Prag, takipçisi en aktif olan destinasyonlar arasında yer almaktadır. Takipçi sayısı, diğer kriterleri de etkiyen bir husus olduğundan, DPO'ların takipçi sayılarını arttırmaları durumunda, diğer performans kriterlerinde ilerleme kaydetme şansları olacaktır. Fakat, Prag örneğinden yola çıkılarak sadece takipçi sayısının genel performansın tespiti için yeterli olmadığı, bunun yerine aktif takipçi sayısının dikkate alınması gerektiği unutulmamalıdır. DPO'ların aktif kullanıcı sayılarını arttırmak için farklı hedef kitlelere hitap eden sosyal medya stratejileri geliştirmeleri tavsiye edilebilir. Örneğin, hedef kitlelere yönelik e-reklamlar bu hususta etkili olabilir.

Bir diğer sosyal medya kanalı olan Instagram, bu çalışmada incelenen DPO'ların tümünün hesap sahibi olduğu bir platformdur. Bu platformda, Paris en fazla takipçi sayısına sahip destinasyon olarak dikkat çekmektedir. Buna karşın, müşteri bağlılığını yansıtan kriterler olarak bilinen beğeni ve yorum sayıları açısından Londra, Paris'ten daha iyi bir konumdadır. Bunun başl1ca nedeni, Londra'nın daha fazla sayıda gönderi yapması, diğer bir ifade ile sosyal medya ortamında daha aktif bir şekilde rol oynamasıdır. Ancak, gönderi başına beğeni ve yorum sayıları yakından incelendiğinde, Paris'in Londra'ya k1yasla daha iyi performansa sahip olduğu görülmektedir. Özet olarak, Londra DPO'su Paris'e 
göre Instagram platformunda daha çok gönderi yapmasına karşın, Paris'in sahip olduğu takipçiler göreceli olarak daha aktiftir. Bu nedenle Paris'in takipçilerinin destinasyona daha bağlı olduğu yönünde bir çıkarım yapılabilir. Bu bağlamda, müşteri bağlılığının tespiti için gönderi başına yapılan beğeni, yorum ve paylaşım sayısının, toplam yapılan beğeni, yorum ve paylaşım sayısından daha fazla önem taşıdığı söylenebilir.

Araştırmada ele alınan bir diğer sosyal medya kanalı Youtube'tur. Bu platformu, DPO'ların fazla tercih etmedikleri dikkat çekmektedir. Nitekim Prag ve Amsterdam'ın bu kanalda hiçbir resmi hesabı bulunmamaktadır. Ayrıca İstanbul DPO'su bir sene boyunca hiçbir paylaşımda bulunmamış, Antalya bir, Roma üç ve Milano altı paylaşım yapmıştır. Youtube'nin bir sosyal medya mecrası olarak diğer destinasyonca tercih edilmemesi, rekabet üstünlüğü sağlamak isteyen destinasyonlar açısından bir fırsat oluşturabilir. Bu platformda kullanıcıların dikkatini çekecek paylaşımlar yapılması halinde, ilgili DPO'lar daha fazla takipçi sayısına ulaşabilir. Youtube'ta en fazla abone sayisına sahip olan destinasyon Londra, en çok video sayısına sahip olan destinasyon ise Paris'tir. Ancak, Viyana müşteri bağlılığının göstergelerinden olan görüntülenme, beğeni ve yorum sayısının yüksekliği açısından başarılıdır. Bu başarının nedenleri arasında DPO'nun hedef kitlesini yakından tanıması ve onların beklentilerine hitap eden videolar yayınlaması bulunabilir.

Çalışmanın sonuçları sosyal medya ortamında yapılan DPO gönderilerinin sayısı açısından Twitter'ın ilk sirada, Youtube'un son sirada yer aldığını ortaya koymuştur. DPO'lar tarafından Twitter'ın bir sosyal medya kanalı olarak diğerlerine göre daha aktif bir şekilde kullanılmasının başlica sebebi olarak bu platforma üye olan kullanıcıların durumlarını sıklıkla güncellemeleri gösterilebilir. Bu husus, daha önce yapılan araştırmalarda da ortaya konmuştur (Java vd. 2007; Hays, Page ve Buhalis 2013; Uşaklı, Koç ve Sönmez 2017). Youtube'un DPO'lar tarafından bir sosyal medya kanalı olarak fazla tercih edilmemesinin başlıca sebepleri arasında kullanım için gereken zamanın ve kaynakların fazlalığı gösterilebilir (Uşaklı, Koç ve Sönmez 2017).
Çalışma amaçlarına paralel olarak, son aşamada DPO'ların sosyal medya performansı ile ziyaretçi sayıları arasındaki ilişki ele alınmıştır. Analiz sonuçları Facebook sayfalarının beğeni sayısı, Twitter ve Instagram sayfalarının takipçi sayısı ile destinasyonların ziyaretçi sayıları arasında anlamlı bir ilişki olduğunu yansıtmıştır. Sadece Youtube kanalının abone sayısı ile destinasyon ziyaretçi sayısı arasında anlamlı bir ilişki söz konusu değildir. DPO'ların sosyal medya performansı ile destinasyon ziyaretçi sayıları arasındaki ilişki göz önüne alındığında, destinasyonlar arası rekabette başarı sağlamak ve sosyal medya ortaminda etkili bir pazarlama stratejisi uygulamak için, DPO'ların sosyal medya performans1nı sürekli olarak takip etmeleri ve performansını arttırmaya yönelik girirşimlerde bulunmaları gerektiği söylenebilir.

Bu çalışma ile destinasyon pazarlama organizasyonlarının sosyal medya performansı ve destinasyonların ziyaretçi sayıları arasındaki ilişki ortaya koyulmuş ve bu açıdan ilgili alanyazına önemli bir katkı sağlanmıştır. Ayrıca, önceki çalışmalarda (Örneğin Hays, Page ve Buhalis 2013; Uşaklı, Koç ve Sönmez 2017) destinasyonların sosyal medya performansı daha ziyade ülke bazında değerlendirilmiş olmasına karşın, bu çalışmada Avrupa'da en fazla turist çeken destinasyonları şehir bazında ele alınmıştır.

DPO'lar sosyal medya hesaplarını yönetirken, hedef pazarlarını göz önünde bulundurmalıdır. $\mathrm{Bu}$ araştırma kapsamında incelenen DPO web sitelerinin çoğu farklı dillerde kullanıma olanak sağlamaktadır. Ancak DPO'ların farklı dillerde sosyal medya hesaplarının bulunmadığı görülmektedir. İnternet ve sosyal medya kullanicılarının bir kısmı, kendi dillerinde sosyal medya hesaplarına sahip olmadığından, farklı dillerde yapılandırılmış DPO web sitelerini ya hiç takip edemeyebilir ya da takip edebilseler de yapilan paylaşımları anlamakta zorluk çekebilirler. Bu da yapılan paylaşımların etkisini ve aktif kullanıcı sayısını olumsuz yönde etkileyebilir. Bu nedenle, farklı dillerde sosyal medya hesaplarına sahip olmak ve bunları etkin şekilde kullanmak, DPO'ların sosyal medya performansına katkı sağlayacaktır. Bu ve benzeri stratejiler sayesinde 
DPO'ların takipçileri ile arasındaki bağ güçlenebilir, müşteri bağlılığı desteklenebilir ve potansiyel turistlerin destinasyonu ziyaret etme niyetleri yükseltilebilir.

Sosyal medya ortamında DPO'ların gösterdiği performans, destinasyonların pazarlama stratejisinin önemli bir unsuru ve belirleyicisidir. Bu sebeple sosyal medya stratejileri belirlenirken ve sosyal medya hesaplarını yönetilirken hem sosyal medya departmanı kurulmalı hem de profesyonel sosyal medya uzmanı şirketlerden danışmanlık hizmeti alınmalıdır.

Bu çalışmada sadece Avrupa'da en çok ziyaret edilen destinasyonlar üzerinde durulmuştur. İleride yapılacak çalışmalarda belli turizm türlerinde (kültür ve macera gibi) rekabet içerisinde olan destinasyonların performansı incelenebilir. Bu araştırmada destinasyonların bir yıl içerisindeki genel sosyal medya performansı incelenmiştir. Sosyal medya gibi sürekli değişen ve gelişen bir alanda destinasyonların performansinın mevsimsel, aylık veya haftalık olarak incelenmesiyle daha farklı sonuçlara ulaşılabilir.

\section{KAYNAKÇA}

Aghaei, S., Nematbakhsh, M. A. ve Farsani, H. K. (2012). Evolution of the World Wide Web: From WEB 1.0 TO WEB 4.0, International Journal of Web \& Semantic Technology, 3(1): 1- 10 .

Brown, R. (2018). The Impact of Social Media on Travel Inspiration, http://www.olapic.com/resources/the-impact-ofsocial-media-on-travel-inspiration_blog p1aw-f1tr-v1tht1sm/, Erişim tarihi: 3 Ağustos 2018.

Buhalis, D. ve Law, R. (2008). Progress in Information Technology and Tourism Management: 20 Years on and 10 Years After the Internet the State of Etourism Research, Tourism Management, 29(4): 609-623.

Dreamgrow.com İnternet Sitesinden Alınan Elektronik Referans. (2018). https://www.dreamgrow.com/top-15-mostpopular-social-networking-sites, Erişim tarihi: 25 Şubat 2018.

Euromonitor.com internet sitesinden alınan elektronik referans. (2017). http://go.euromonitor.com/Top_100_City_ Destinations_WTM_Form_Download.html\#download-link, Erişim tarihi: 11 Nisan 2018.

Hays, S., Page, S. J. ve Buhalis, D. (2013). Social Media as a Destination Marketing Tool: Its Use by National Tourism Organisations, Current Issues in Tourism, 16(3): 211-239.

Java, A., Song, X., Finin, T. ve Tseng, B. (2007). Why We Twitter: Understanding Microblogging Usage and Communities, 9th WebKDD and 1st SNA-KDD 2007 Workshop
On Web Mining And Social Network Analysis (ss. 56-65). ABD: San Jose, Kaliforniya.

Johnson, B. (2011). Visit Britain to Cut Jobs and Refocus, https://www.marketingweek.com/2011/02/09/visitbritainto-cut-jobs-and-refocus, Erişim tarihi: 15 Ocak 2018.

Kabadayi, S. ve Price, K. (2014). Consumer - Brand Engagement on Facebook: Liking and Commenting Behaviors, Journal of Research in Interactive Marketing, 8 (3): 203-223.

Kaplan, A. ve Haenlein, M. (2010). Users of the World, Unite! The Challenges and Opportunities of Social Media, Business Horizons, 53(1): 59-68.

Lu, Y., Chen, Z. ve Law, R. (2018). Mapping the Progress of Social Media Research in Hospitality and Tourism Management from 2004 to 2014, Journal of Travel \& Tourism Marketing, 35(2): 102-118.

Lund, N. F., Cohen, S. A. ve Scarles, C. (2018). The Power of Social Media Storytelling in Destination Branding, Journal of Destination Marketing \& Management, 8: 271-280.

Milwood, P., Marchiori, E. ve Zach, F. (2013). A Comparison of Social Media Adoption and Use in Different Countries: The Case of the United States and Switzerland, Journal of Travel \& Tourism Marketing, 30(1-2): 165-168.

Munar, A. M. (2012). Social Media Strategies and Destination Management, Scandinavian Journal of Hospitality and Tourism, 12(2): 101-120.

Roque, V. ve Raposo, R. (2016). Social Media As A Communication And Marketing Tool in Tourism: An Analysis Of Online Activities From International Key Player DMO, Anatolia An International Journal of Tourism and Hospitality Research, 27 (1): 58-70.

Ružić, D. ve Biloš, A. (2010). Social Media in Destination Marketing Organisations (DMOs), Conference: Tourism \& Hospitality Industry 2010, New Trends in Tourism and Hospitality Management. Hirvatistan: Opatija.

Schegg, R., Liebrich, A., Scaglione, M. ve Ahmad, S. F. (2008). An Exploratory Field Study of Web 2.0 in Tourism. İçinde P. O'Connor, W. Höpken, ve U. Gretzel (Editörler), Information and Communication Technologies in Tourism 2008 (ss. 152-163). Viyana: Springer.

Stankov, U., Lazić, L. ve Dragićević, V. (2010). The Extent of Use of Basic Facebook User-generated Content by the National Tourism Organizations in Europe, European Journal of Tourism Research, 3(2): 105-113.

Statista.com İnternet Sitesinden Alınan Elektronik Referans. (2018). https://www.statista.com/statistics/185454/ technology-used-to-plan-leisure-travel-in-the-us-2011, Erişim tarihi: 3 Ağustos 2018.

Uşakl1, A., Koç, B. ve Sönmez, S. (2017). How 'Social' are Destinations? Examining European DMO Social Media Usage, Journal of Destination Marketing \& Management, 6: 136-149.

Wearesocial.com internet sitesinden alınan elektronik referans. (2018). https://wearesocial.com/special-reports/ digital-in-2017-global-overview, Erişim tarihi: 3 Ağustos 2018.

Xiang, Z. ve Gretzel, U. (2010). Role of Social Media in Online Travel Information Search, Tourism Management, 31(2): 179-188. 


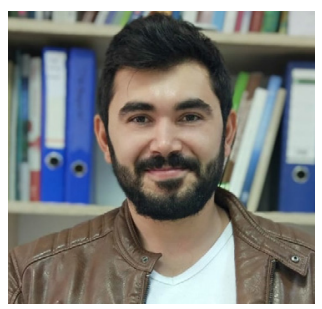

Doğuş KILIÇARSLAN

Adnan Menderes Üniversitesi Turizm İşletmeciliği ve Otelcilik Yüksekokulu Seyahat İşletmeciliği ve Turizm Rehberliği Bölümü'nden mezun oldu (2014). Yüksek lisans derecesini Akdeniz Üniversitesi Turizm İşletmeciliği ve Otelcilik dalından aldı (2016). Halen Akdeniz Üniversitesi'nde Turizm İşletmeciliği Dalı'nda doktora eğitimine devam etmektedir. Temel çalışma alanları, tur rehberliği ve turizm pazarlamasıdır.

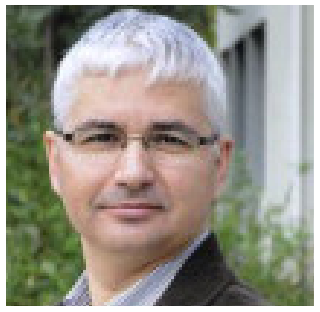

Tahir ALBAYRAK

Kara Harp Okulu Komutanlığı'ndan mezun oldu (1992). Yüksek lisans (2004) ve doktora (2008) derecelerini Akdeniz Üniversitesi İktisadi ve İdari Bilimler Fakültesi İşletme dalından aldı. Akdeniz Üniversitesi Turizm Fakültesi'nde çalışmaya başladı (2009). Doçentlik unvanını Pazarlama alanından aldı (2014). Halen Akdeniz Üniversitesi Turizm Fakültesi'nde görev yapmaktadır. Temel çalışma alanları, turizm pazarlaması ve hizmet kalitesidir. 